Publicación semestral. ISSN 2215-4906

Volumen 78 - Número 2

Enero - Junio 2019

\title{
Fotografías del sida: médicos y homosexuales en la prensa costarricense (1985-1990)
}

Photographs of AIDS: Doctors and Homosexuals

in the Costa Rican Press (1985-1990)

José Daniel Jiménez Bolaños

Mario Andrés Soto Rodríguez

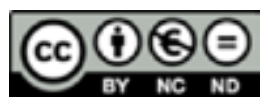

Esta obra está bajo una licencia Creative Commons

Reconocimiento-No comercial-Sin Obra Derivada 


\title{
Fotografías del sida: médicos y homosexuales en la prensa costarricense (1985-1990)
}

\author{
Photographs of AIDS: Doctors and Homosexuals \\ in the Costa Rican Press (1985-1990) \\ José Daniel Jiménez Bolaños ${ }^{1}$ \\ Universidad de Costa Rica \\ Costa Rica \\ Mario Andrés Soto Rodríguez ${ }^{2}$ \\ Universidad de Costa Rica \\ Costa Rica
}

Recibido: 14 de febrero del 2018 Aprobado: 16 de mayo del 2018

\begin{abstract}
Resumen
El artículo propone realizar un análisis de las fotografías que se incluyeron en las noticias relacionadas al VIH/sida entre 1985-1990 en el periódico La Nación. Se elabora una contextualización sobre el surgimiento del VIH/sida en el ámbito mundial y Costa Rica, en particular. Se parte de la perspectiva teórica de Barthes acerca del análisis fotográfico y se establecen tres categorías para abordar el material: el sida como desastre natural y avanzada militar, la representación del saber médico y las políticas de la vergüenza. Entre los principales resultados se destaca la problematización del vínculo entre fotografía y texto para producir connotaciones específicas; el protagonismo masculino dentro del saber médico y una transformación de la estética de la homosexualidad, el paso de un exotismo a un ocultamiento por vergüenza. Se concluye que la injuria, la vergüenza y su relación con las representaciones visuales son ejes fundamentales que permiten abordar el tema del VIH/sida.
\end{abstract}

Palabras clave: fotografía; imagen; Sida; VIH; Costa Rica

1 Docente de Historia e investigador en el Centro de Investigaciones en Identidad y Cultura Latinoamericanas (CIICLA), ambos de la Universidad de Costa Rica. Licenciado en Historia por la Universidad de Costa Rica. Correo electrónico: josedaniel.jimenez@ucr.ac.cr

2 Docente en la Escuela de Psicología de la Universidad de Costa Rica y psicólogo clínico. Máster en Teoría Psicoanalítica por la Universidad de Costa Rica. Correo electrónico: mariosoto4@gmail.com 


\begin{abstract}
The article proposes an analysis of the photographs that were included in the news related to HIV / AIDS between 1985-1990 in the newspaper La Nación. A contextualization about the emergence of HIV / AIDS worldwide and in Costa Rica is made. The theoretical perspective of Barthes about photographic analysis is used, and three categories are established to address the material: AIDS as a natural disaster and a military vanguard, the representation of medical knowledge, and the politics of shame. Among the main results we can find the problematization of the link between photography and text to produce specific connotations; the masculine protagonism within the medical knowledge, and a transformation of the aesthetics of homosexuality, shifting from an exoticism to a concealment by shame. As a conclusion, insult and shame, and their relationship with visual representations, are fundamental axes that allow us to address the issue of HIV / AIDS.
\end{abstract}

Keywords: photography; image; AIDS; HIV; Costa Rica 
Fotografías del sida:

Artículos

médicos y homosexuales en la prensa costarricense (1985-1990)

\section{Reflexiones teórico-metodológicas sobre el análisis fotográfico}

Algunas investigaciones han buscado hacer un análisis sobre las diferentes representaciones gráficas en relación con el $\mathrm{VIH} /$ sida, desde campañas de prevención, pinturas y fotografías (Johnny \& Mitchell, 2007; Oyebode \& Unuabonah, 2013; Bleiker \& Kay, 2007; Varas-Díaz \& Toro-Alfonso, 2003). Estas, aunque hacen uso de una gran variedad de estrategias metodológicas para acercarse al aspecto visual y simbólico del virus, coinciden en la necesidad de darle una mayor cabida a esta forma de análisis que ha quedado relegada. Debido a que la gran mayoría de estudios que se han elaborado -principalmente desde las Ciencias médicas y las Ciencias sociales- tienden a concentrarse en otro tipo de aspectos, tales como su impacto en el modelo económico y la legislación, experiencias en servicios de salud, diagnósticos, tratamientos, caracterización de población "de riesgo" y programas educativos y de prevención, y los análisis discursivos en perspectiva histórica.

En ese sentido, Philippe Dubois (2015) hace un recorrido histórico sobre las diferentes posiciones que se han desarrollado a lo largo de la historia con relación a la teoría fotográfica y distingue tres momentos: el primero donde la fotografía es concebida como una representación objetiva de la realidad. Esta perspectiva se desarrolla a partir del siglo XIX y, a pesar de tener múltiples polémicas, su premisa básica era que la fotografía podía ser considerada como una copia fidedigna de aquello que retrataba, debido a que el producto final era el resultado de procedimientos mecánicos, químicos y ópticos. Gracias a esto se consolidó una posición dicotómica entre la obra de arte (imaginaria, subjetiva, interpretativa) y la fotografía (concreta, objetiva, documental), la cual tuvo un gran peso en la formulación de las discusiones y polémicas teóricas en este primer momento.

Un segundo momento es el de la fotografía como transformación de lo real, el cual rompe con la perspectiva anterior y propone -desde una óptica más deconstruccionista- que la supuesta "realidad" estaba codificada por la cultura, la sociedad, la estética y la técnica. Es así como la fotografía deja de ser considerada un agente reproductor neutro y se propone que es capaz de producir efectos deliberados, de igual forma que la lengua, en tanto "asunto de convención e instrumento de análisis e interpretación de lo real" (Dubois, 2015, p. 61). De esta forma, la imagen fotográfica pasaría a ser un conjunto de códigos atravesados por la arbitrariedad, la cultura y la ideología.

Como tercer y última etapa en este desarrollo teórico, Dubois menciona a la fotografía como huella de un real, una perspectiva que intenta retomar lo "real" y "esencial" desde un modo distinto al de la primera etapa. Se argumenta que en la fotografía habría un referente -único, singular- que interpela de formas variadas al observador. Dentro de esta tercera posición, Barthes (2016) busca analizar la fotografía desde una perspectiva ontológica, llegar a la raíz de la misma y evidenciar cuál era el rasgo que permitiría distinguirla de 
otro tipo de imágenes. Para el autor, el referente fotográfico sería algo necesariamente real, sin el cual no podría haber fotografía, al contrario de lo que pasa con una pintura donde se puede producir una realidad sin algún referente específico. En la fotografía "jamás puedo negar que la cosa estuvo ahi”" (p.119), destaca el autor.

Ahora bien, específicamente, en lo que respecta a la fotografía periodística, Barthes (2015) señala que esta ocupa un lugar particular, ya que no necesariamente es concebida como una obra artística en sí, sino que se le coloca en el lugar de un mensaje que supuestamente transmite información fidedigna sobre determinados acontecimientos. El autor señala tres elementos que conformarían el conjunto del mensaje: una fuente emisora, un canal de transmisión y un medio receptor. Sobre estos especifica lo siguiente:

La fuente emisora es el grupo de técnicos que forman la redacción del periódico: unos hacen las fotos otros eligen una en particular, la componen, la tratan, y otros, por último, la titulan, le ponen un pie y la comentan. El medio receptor es el público que lee el periódico. Y el canal de transmisión, el propio periódico o, para hablar con más precisión, un complejo de mensajes concurrentes que tienen a la fotografía como centro, pero cuyo entorno está constituido por el texto, el titular, el pie de foto, la compaginación y, también ... la misma denominación del periódico (p. 11).

De lo anterior, es posible desprender que, aun cuando la fotografía es capaz de captar algo de lo real, para el momento en que esta es publicada por un medio, ya ha sido seleccionada de entre otras imágenes, modificada y acompañada de diversos textos que sesgan y regulan algunas de las significaciones que la imagen sería capaz de producir en aquellos que conformen el medio receptor. También, se debe tener en cuenta que lo hace desde una óptica particular y parcial (la de quien realiza el acto fotográfico). De esta forma, el mensaje emitido por el medio de comunicación estaría compuesto por, al menos, dos estructuras diferentes "en una (el texto), la sustancia del mensaje está constituida por palabras, en la otra (la fotografía), por líneas, superficies, tonos" (Barthes, 2015, p.12). Debido a esto, el autor propone un método, en el cual cada una de las partes es analizada por separado para, posteriormente, abordar la manera en que estas se complementan en la producción del mensaje.

En lo que respecta específicamente al análisis de la fotografía en tanto objeto dotado de autonomía estructural dentro del mensaje, Barthes (2015) indica que esta, al ser el "analogón perfecto de la realidad", "estaría exclusivamente constituida y colmada por un mensaje 'denotado' que la llenaría por completo" (pp.14-15). Entonces, en el acto de construir uno o varios sentidos a partir de la sustancia analógica que es la imagen, por medio de su paso -siempre incompleto- al lenguaje, es que se accede a su connotación, en tanto "segundo mensaje, extraído de un código que es la lengua" (p.15). Es importante señalar que, entonces, 
Fotografías del sida:

Artículos

médicos y homosexuales en la prensa costarricense (1985-1990)

las fotografías utilizadas en prensa son "un objeto trabajado, escogido, compuesto, elaborado, tratado de acuerdo con unas normas profesionales, estéticas o ideológicas que constituyen otros factores de connotación. Por otra parte, esa misma fotografía no solamente se percibe, se recibe, sino que se lee" [¿enfásis agregado o del original?] (Barthes, 2015, p. 16).

La lectura fotográfica, de acuerdo con Barthes (2015), estaría entonces supeditada a los diversos procedimientos de connotación a los que es sometido el análogo fotográfico, los cuales tienen lugar en diversos momentos de la producción de la imagen; como lo sería la manipulación del entorno antes de la captura (trucaje, pose y objetos), la manipulación de la composición y los colores de la imagen (fotogenia, esteticismo y sintaxis) o, bien, la elaboración y selección de textos que acompañen la fotografía. A partir de esto, se desprende que los códigos por medio de los cuales es descifrado el analogón, son históricos y "dependen del 'saber' del lector, igual que si fuera una verdadera lengua, que solo es inteligible para el que aprende sus signos” (p. 26).

\section{Descripción metodológica}

Para elaborar este artículo, se hizo una búsqueda sistemática en el periódico La Nación entre los años 1985-1990, para recopilar los artículos, reportajes y noticias cuyo tema principal fuera el $\mathrm{VIH} /$ sida y contaran con alguna fotografía. Una vez hecha la recolección del corpus de información, se revisaron todas las fotografías -en relación con los textos que las acompañan- para proceder a construir las categorías (connotaciones) de análisis que se desarrollarán más adelante. Es importe resaltar que las noticias concernientes a este padecimiento comienzan a aparecer en los medios de comunicación a partir de 1983, provenientes de agencias de prensa estadounidense y consistían en pequeños recuadros de texto, lo cual continuará así por dos años, hasta que en agosto de 1985 comienzan a aparecer los primeros reportajes que incluyen imágenes, las cuales hacen referencia a diversas temáticas.

\section{Contextualización de la aparición del VIH/sida en Costa Rica}

A inicios de la década de 1980, varias personas acuden a los servicios de salud en Estados Unidos de América, con una serie de cuadros que la medicina cataloga como "extraños". Las características particulares de este "nuevo mal" resultan confusas para el conocimiento médico de la época, precisamente, porque rompen con la forma en que se concebía la enfermedad. De acuerdo con Grmek (2004), en 1981 los médicos logran dar cuenta de este padecimiento misterioso que pensaron provenía del extranjero, ya que no les era posible pensar que una condición así se hubiera gestado en el Primer Mundo. Por lo que, seguramente, debía haberse originado en países subdesarrollados, en grupos marginalizados y con principios morales cuestionables. La falta de un nombre científico para 
el misterioso padecimiento produjo que se empezaran a enunciar una serie de alternativas como "neumonía gay", "cáncer gay" e incluso se emplea un acrónimo de apariencia más científica, que es GRID (Gay-Related Inmune Deficiency) (Inmunodeficiencia homosexual) (Grmek, 2004). Sin embargo, la aparición de casos en hombres heterosexuales y mujeres hace que se reconsidere la exclusividad del agente patógeno a determinado grupo social específico. Esto hará que la teoría de un contagio con rasgos comunitarios tome más fuerza y que las hipótesis que planteaban la afección como el resultado de un agente infeccioso transmitido por vía sexual se vuelvan más relevantes.

Es hasta 1982 que la enfermedad recibe su nombre de manera definitiva, pues se logra obtener pruebas de su causa viral y se comienza a reconocer su presencia en todos los continentes. En 1983, se logra aislar el virus responsable y su papel etiológico es reconocido hasta 1984, lo cual posibilitó el desarrollo y perfeccionamiento de test serológicos para su identificación durante 1985. La confirmación de posibilidad de contagio entre heterosexuales se dio de forma más tardía, pues se identificaron hasta 1983, debido a la aparición de síntomas en compañeras de bisexuales y toxicómanos, mientras era siempre el hombre el que tenía el principal factor de riesgo, exceptuando el caso de las mujeres que ejercían el trabajo sexual (Grmek, 2004). Este autor también resalta que la aparición del $\mathrm{VIH} /$ sida en tanto pandemia, se posibilitó gracias a los avances científicos y tecnológicos de nuestra época. Es decir, la cepa agresiva del virus pudo haber formado parte de las enfermedades humanas desde hace mucho tiempo, pero sus características no eran detectables, así como tampoco era muy prolongado el período de contagio de quien estaba infectado, debido a que su período de vida se veía acortado antes de poder transmitirlo de forma cuantitativamente significativa.

Al contrario de lo que sucede en gran parte del mundo, la aparición del $\mathrm{VIH} /$ sida en Costa Rica se da de una forma diferenciada. El primer caso registrado corresponde a un hemofílico en 1980 (Mata, 1988), cuyo diagnóstico se realizó retrospectivamente, por medio de una revisión de la autopsia en 1983 y una confirmación por medio de un análisis realizado en 1985 sobre un suero congelado que se tenía del sujeto. Los hemofílicos se mantuvieron como los únicos infectados diagnosticados hasta que en 1985 aparece el primer registro de un homosexual. Esto, de acuerdo con Mata (1988), permite determinar que el virus circuló en el país desde el inicio de la década de 1980 y, por eso, los primeros casos de sida "autóctonos" se desarrollaron hasta la segunda mitad de dicha década.

Ante la confirmación del peligro que representaba la utilización de productos sanguíneos para tratar a los hemofílicos, el Ministerio de Salud decidió tomar medidas preventivas estrictas. Estableció una serie de regulaciones en lo que respecta a la prevención del contagio y el control de los bancos de sangre nacionales, lo cual hizo que las posibilidades 
Fotografías del sida:

Artículos

médicos y homosexuales en la prensa costarricense (1985-1990)

de transmisión del virus por medio de una transfusión después de 1984 fueran muy bajas (Mata, 1988). Sin embargo, una serie de decisiones deliberadas por parte de la empresa extranjera encargada de producir e importar los productos sanguíneos a Costa Rica, para ser utilizados en la Caja Costarricense del Seguro Social (CCSS), incidió en el aumento de contagio en personas hemofílicas, situación que se repitió en diferentes partes de Asia y América Latina (Soto, 2017).

La respuesta del gobierno se cristalizó en la creación de la Comisión Nacional de SIDA, una institución conformada por diferentes especialistas -principalmente médicos- que se encargó de ser el puente entre la ciudadanía, las políticas de prevención y el accionar político. En los primeros años de la aparición del virus, las acciones llevadas a cabo por el Estado se caracterizaron por su violencia en la búsqueda de supuestos infectados, en las propuestas para hacer obligatorios los exámenes de detección del virus en ciertos grupos y en las manifestaciones mediáticas de miembros importantes del sector público (Jiménez, 2016).

A partir de 1985, empieza a desarrollarse una discusión mediática bastante intensa, en donde el discurso médico tuvo un papel fundamental en la propagación de ideas sobre la sexualidad y la creación de límites simbólicos entre la normalidad y la desviación (Jiménez \& Bahena, 2017). Fue por medio de los medios de comunicación -principalmente escritos- que se difundieron imágenes y fotografías sobre el $\mathrm{VIH}$ y el sida. Dichas propuestas visuales dotaron al saber institucionalizado, a diversas subjetividades y a la incertidumbre y a la angustia frente al virus de una serie de construcciones imaginarias que tenían efectos en el medio receptor. A continuación, se hace un análisis sobre las diferentes fotografías utilizadas por La Nación para abordar el tema del VIH/sida.

\section{El sida como desastre natural y avanzada militar}

La primera noticia encontrada, que integra imagen al discurso sobre el $\mathrm{VIH} /$ sida en el periódico La Nación, habla sobre los descubrimientos realizados por el Instituto Pasteur en torno a la estructura del virus. También realiza una serie de proyecciones en torno a cómo se comportará el virus en el futuro y las posibles tasas de contagio en determinadas poblaciones. Así, se pronostica un contagio masivo en hombres homosexuales (Smirnow, 27 de enero de 1985, p. 20). Curiosamente, la imagen que acompaña esta noticia no parece tener relación alguna con el texto, ya que hace referencia a una serie de inundaciones que están ocurriendo en Argentina para ese entonces. En la fotografía se pueden observar los techos de unos automóviles que se encuentran cubiertos por el agua y un escenario urbano desbordado por el desastre natural.

ESCENA. Revista de las artes, 2019, Vol. 78, Núm. 2 (enero-junio), pp. 125-149 
En primera instancia, esta asociación de elementos parecería ser un error en la diagramación de la noticia, en donde la propagación e identificación de un virus no tiene relación con el flujo de agua desmedido. Sin embargo, al adentrarse en el contenido del texto y las proyecciones catastróficas en las cuales la población mundial se encuentra en riesgo de contagio, estas posibilitan pensar en dicha fotografía como una metáfora, en la que el virus aparece como un agente natural de gran potencial destructivo que se está infiltrando en las zonas urbanas del mundo y amenaza con cubrirlo y destruirlo todo.

Imagen 1. Científicos identifican virus que causa el SIDA

$20 \mathrm{~A} \quad$ Lo Noción, domingo 27 de enero de 1985

\section{Científicos identifican virus que causa el SIDA}
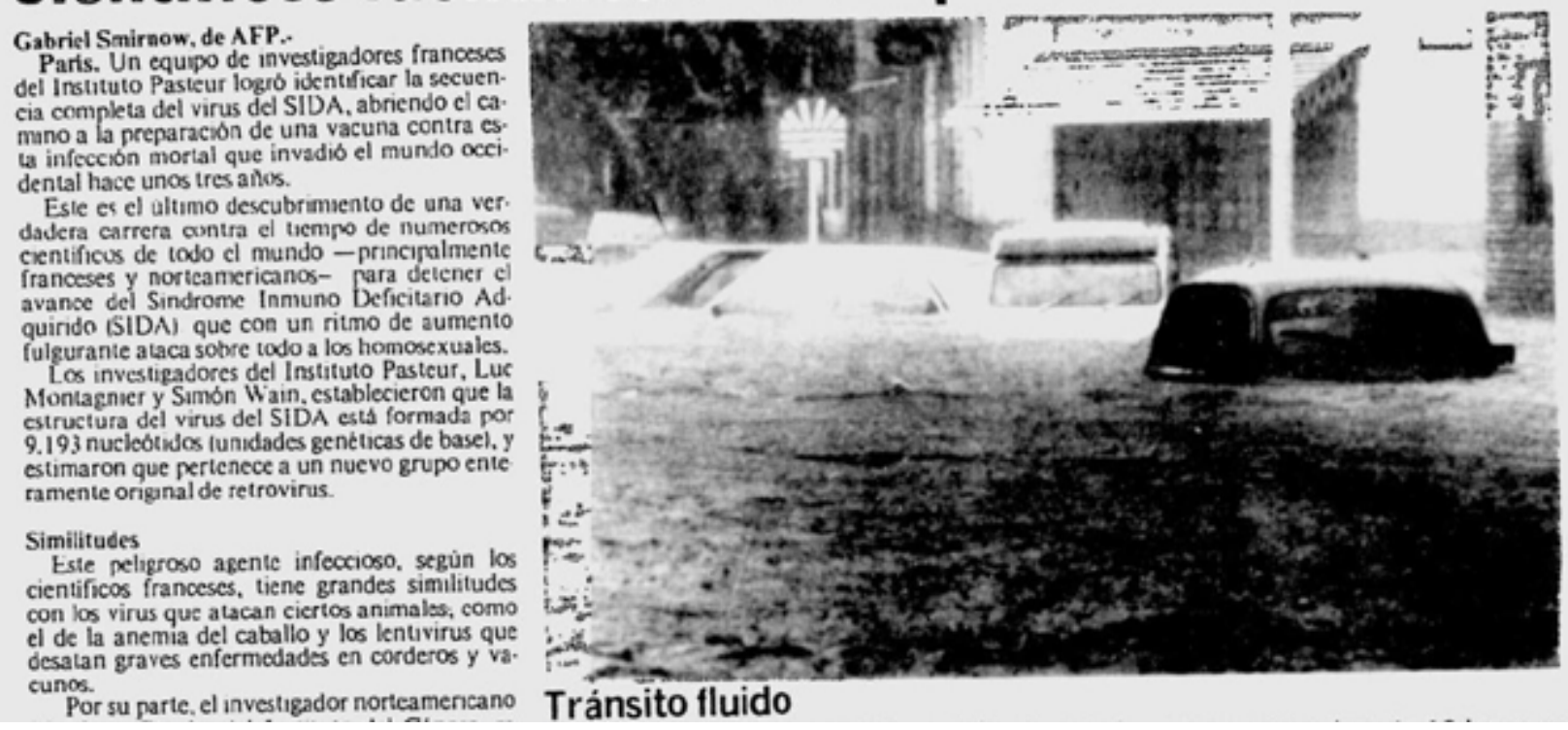

Fuente: Smirnow, G. (27 de enero de 1985).

Es de destacar, además, el continuo uso que se hace en el texto de la noticia de metáforas militares para referirse a la situación actual y futura del VIH. Por ejemplo, se menciona que se trata de una infección mortal que ha invadido al mundo occidental. Se caracteriza a la dinámica del virus como algo que avanza a un ritmo fulgurante, que se expande y causa pánico. Se habla del accionar médico como una carrera contra el tiempo, se menciona a la potencial vacuna como la única protección posible contra la enfermedad, se alude 
Fotografías del sida:

Artículos

médicos y homosexuales en la prensa costarricense (1985-1990)

a los homosexuales como el grupo que será mayormente atacado por el virus. En relación con esto, Sontag (2014) indica que la implementación de la metáfora militar en el discurso médico se origina a partir de la Primera Guerra Mundial (en campañas de prevención de la sífilis y posteriormente de la tuberculosis). Esta autora plantea lo siguiente:

La medicina se volvió verdaderamente eficaz y las metáforas militares cobraron nueva credibilidad y precisión solo cuando se consideró que el invasor no era la enfermedad sino el microrganismo que la produce. Desde entonces las metáforas militares han permeado cada vez más todos los aspectos de la descripción de una situación médica dada. La enfermedad es vista como una invasión de organismos extraños, ante la que el cuerpo responde con sus propias operaciones militares, como la movilización de las "defensas" inmunológicas; mientras que la medicina, como en la jerga de la mayor parte de las quimioterapias, es "agresiva" (p. 111).

Una segunda noticia, que se emparenta con la mencionada anteriormente, aparece el 11 de enero de 1987, en la cual la imagen utilizada tampoco tiene relación directa con el texto que la acompaña. El mismo, a su vez, está cargado de metáforas militares, incluso el título de la misma: "Avanza el SIDA". Sin embargo, un análisis más detallado permite observar la construcción de un mensaje a partir de la proximidad de ambas estructuras. La imagen presentada corresponde a una marcha en la ciudad de Nueva York, en la que es posible observar a hombres y mujeres caminando y sosteniendo carteles a favor de la igualdad de derechos para las personas homosexuales, en el primer plano de la fotografía destaca la frase "Equality to homosexuals [lgualdad a los homosexuales]". Dentro del texto se abordan diferentes reacciones que se han suscitado en lugares como Estados Unidos, Australia, Japón e Italia a raíz de la presencia del virus en amplios sectores de la población. Nuevamente, las metáforas militares permean el discurso, entre ellas se habla de que el sida ataca; se menciona a los hemofilicos como las víctimas de esta situación. Además, se evidencia que en varios países se han establecido políticas para evitar el contacto con extranjeros y, finalmente, el título del artículo con la utilización del verbo "avanza".

La puesta en relación de la fotografía que retrata las luchas por Derechos Humanos y sexualidades no hegemónicas, con un titular y un texto que hablan sobre la forma en que el virus del VIH se ha propagado por el mundo posibilita establecer una comparación, en la cual el avance de políticas progresistas en torno a la sexualidad y el reconocimiento de derechos civiles van de la mano con la propagación de un virus. Mismo que, desde esquemas conservadores ha sido propagado exclusivamente por dicha población. Los homosexuales, entonces, son retratados como los soldados de esa avanzada militar que está poniendo en peligro a miles de personas alrededor del mundo.

ESCENA. Revista de las artes, 2019, Vol. 78, Núm. 2 (enero-junio), pp. 125-149 
Imagen 2. Avanza el SIDA

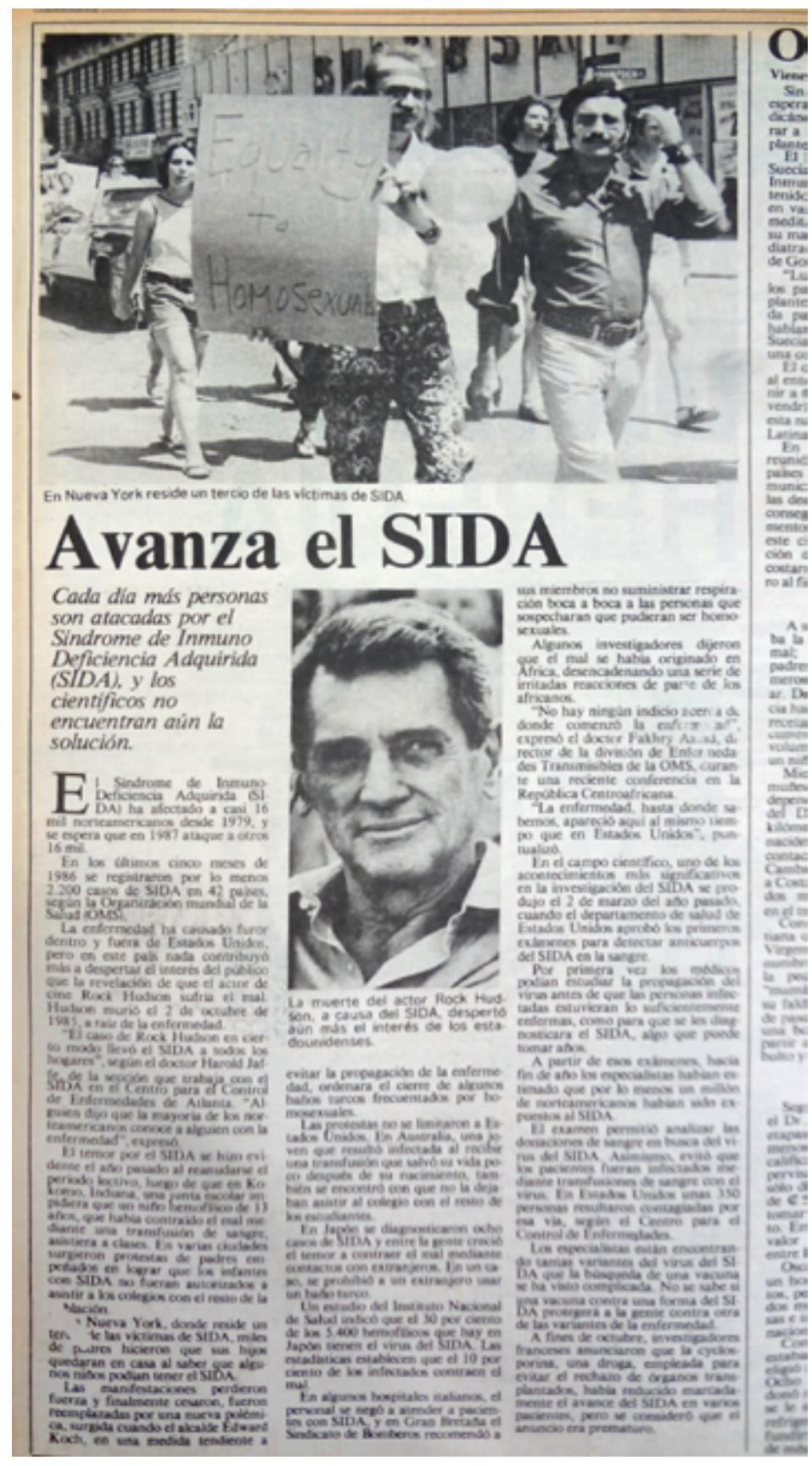

Fuente: Avanza el SIDA (11 de enero de 1987).
Es posible apreciar en las dos noticias analizadas, la utilización de una imagen, que en apariencia no tiene relación directa con el texto que la acompaña, es capaz de producir ciertas significaciones. Por medio de estas, no solo se destaca y exacerba la peligrosidad de un microrganismo -al cual, se le adjudica una agencia e intencionalidad que no poseesino que, además, se posibilita la configuración de determinadas poblaciones como agentes patógenos -más allá de si portan o no el virus-. Incluso, por medio de la implementación de la metáfora militar que destaca Sontag (2014), estas significaciones autorizan a los Estados y a la sociedad civil la implementación de políticas autoritarias que permitan la "protección" del resto de los ciudadanos.

En el momento que se publica la primera noticia, en 1985 , los hemofílicos eran el grupo que contaba con mayor cantidad de personas que vivían con el virus en Costa Rica. No obstante, es importante observar que esta segunda noticia se publica en 1987, año en el que los homosexuales pasan a ser el grupo con mayor porcentaje de portadores del virus y en el que es posible ubicar una gran cantidad de discursos que, con gran virulencia, atacan la expresión de sexualidades no 
Fotografías del sida:

Artículos

médicos y homosexuales en la prensa costarricense (1985-1990)

hegemónicas, lo cual, llega, incluso, a la criminalización. En 1987 se dan múltiples redadas, se publican columnas de opinión abiertamente homofóbicas y se evidencia una cierta concordancia entre las políticas estatales -que buscaban reprimir a un sector de la población con la esperanza de detener el contagio- y la opinión ciudadana (Jiménez, 2016).

\section{El saber médico: los hombres de gabacha y laboratorio}

La aparición del VIH/sida catapultó a los médicos en los medios de comunicación. De forma que, buena parte de las noticias emitidas durante el periodo aquí analizado, cuenta con fotografías de estos, en diversas tareas: utilizando equipo médico, realizando exámenes y revisiones de pacientes, así como impartiendo conferencias de prensa en las que, supuestamente, procuran evacuar las dudas de la población, que son canalizadas por los profesionales en periodismo, que los entrevistan. Para 1985, en los medios de comunicación todavía se discutía acerca de formas de contagio que, eventualmente, serían desechadas: las lágrimas, la saliva, los piquetes de mosquitos, los abrazos y los besos. Es decir, la fotografía de los médicos y su papel como autoridades del saber en los periódicos toma fuerza en un momento donde la incertidumbre, los mitos y la mala información provocaba angustia en la población y falta de consenso entre el mismo gremio médico (Jiménez y Soto, 2018).

Uno de los primeros ejemplos de este apartado corresponde a la noticia titulada "Aclaran que riesgo de contraer Sida es alto en ciertos grupos", en donde se muestra la fotografía de tres médicos, que laboran en el Hospital México, durante una conferencia, en la cual explican los conocimientos científicos que se tenían sobre el virus, su transmisión y las formas de prevención hasta el momento. Uno de los aspectos abordados en dicha noticia es el de los grupos de riesgo, pero además se señala que: "el peligro de que la población contraiga el SIDA es muy bajo porque, aunque el mal se califique como grave, el mayor riesgo lo tienen ciertos grupos, como los homosexuales, drogadictos y hemofilicos" (Aclaran que riesgo, 29 de agosto de 1985, p. 2), con lo cual se determina que el grueso poblacional del país está exento de dichas condiciones: se retrata una Costa Rica sana y heterosexual.

Llama, particularmente, la atención en la fotografía, que en el primer plano se presenta a los médicos vestidos de manera formal, a esto se suma la utilización de una gabacha blanca, que está directamente asociada a la limpieza, el saber y la autoridad médica. Uno de los profesionales en salud sostiene un micrófono en su mano derecha y parece dirigir unas palabras a un público que queda excluido del encuadre (periodistas). En segundo plano es posible apreciar una pizarra, en la cual hay una serie de anotaciones que tienen un carácter de cientificidad, ya que presentan porcentajes y términos médicos como "prurito" y "pólipos", sin embargo, no es posible apreciar la totalidad del mensaje 
Imagen 3. Aclaran que riesgo de contraer Sida es alto en ciertos grupos

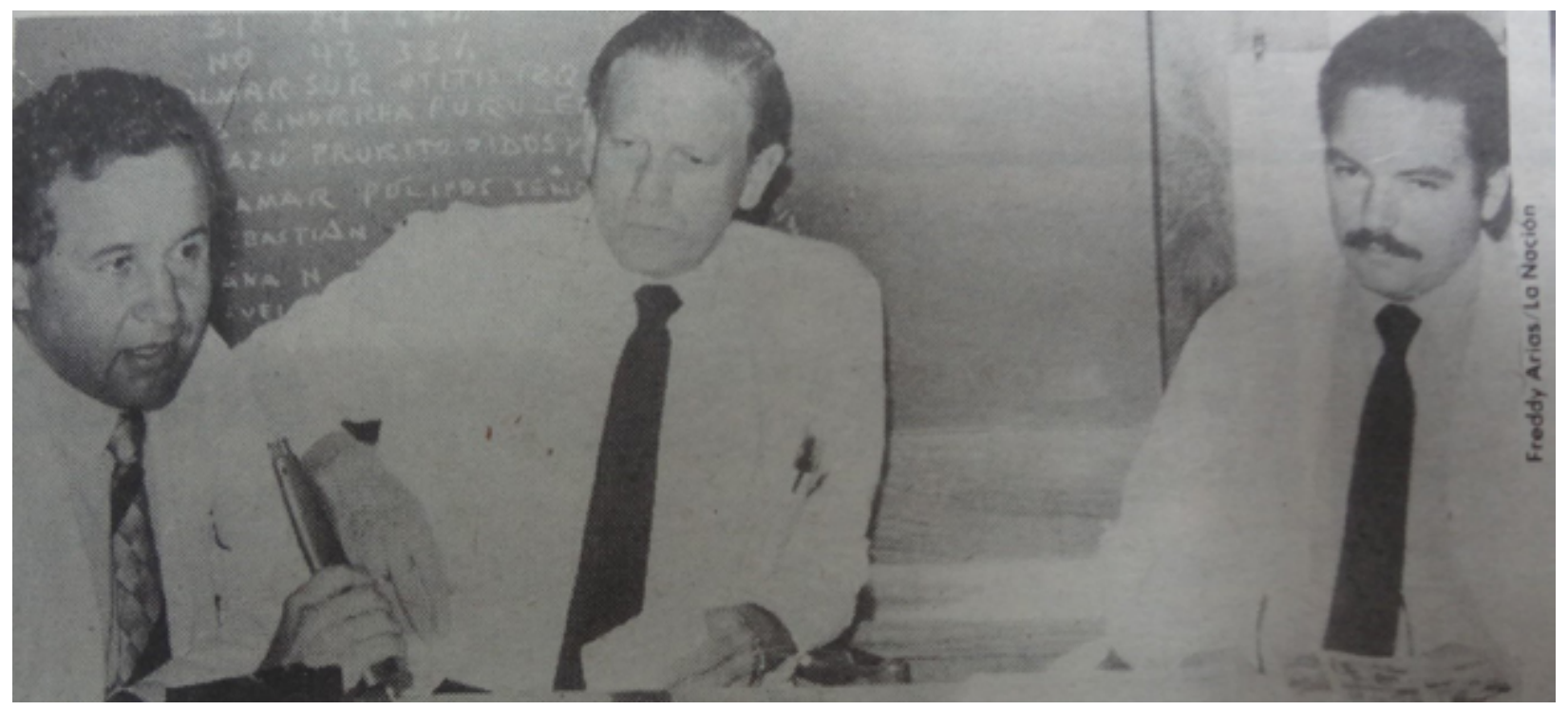

Fuente: Aclaran que riesgo de contraer Sida es alto en ciertos grupos. (29 de agosto de 1985).

En una dinámica similar, otros de los reportajes reiteran la necesidad de que el gremio médico evacuara las dudas y mitos que giran alrededor del VIH/sida. Nuevamente, aparece en las fotografías que acompañan las noticias, profesionales en medicina trabajando en un laboratorio de inmunología. Las poses sugieren que los protagonistas de la imagen están haciendo pruebas con muestras de sangre y reactivos (presencia de objetos de laboratorio) y, al igual que con la fotografía anterior, cada uno de los hombres porta una gabacha blanca que testifica su área de experticia. El contenido de ambas noticias aborda la desmitificación, la transmisión de conocimientos y los avances médicos que se han hecho en torno al padecimiento ${ }^{3}$.

3 La presencia de hombres pertenecientes al gremio médico es una constante durante la segunda mitad de la década de 1980, son múltiples las fotografías donde aparecen, por ejemplo: Crece número de personas con anticuerpos de SIDA (25 de enero de 1987); Pretenden ampliar exámenes de SIDA (5 de enero de 1987); Proponen examen del SIDA a funcionarios públicos (24 de marzo de 1987); Solís, M. (4 de julio de 1987); Usarán derivados sanguíneos sólo en casos de urgencia (10 de julio de 1987); Investigarán uso de droga contra SIDA (12 de mayo de 1987); Marginan a alumnos hijos de pacientes con SIDA (15 de mayo de 1987); SIDA provoca una muerte más (5 de abril de 1987); Limitarán prueba de SIDA (7 de abril de 1987); Niegan discordia entre médicos por el SIDA (14 de abril de 1987); Divergen sobre examen de SIDA (25 de marzo de 1987); Dos casos más de SIDA en el país (22 de agosto de 1987); Primeros dos casos de SIDA en 1988 (8 de enero de 1988). 
Imagen 4. Dudas y mitos que deben desecharse

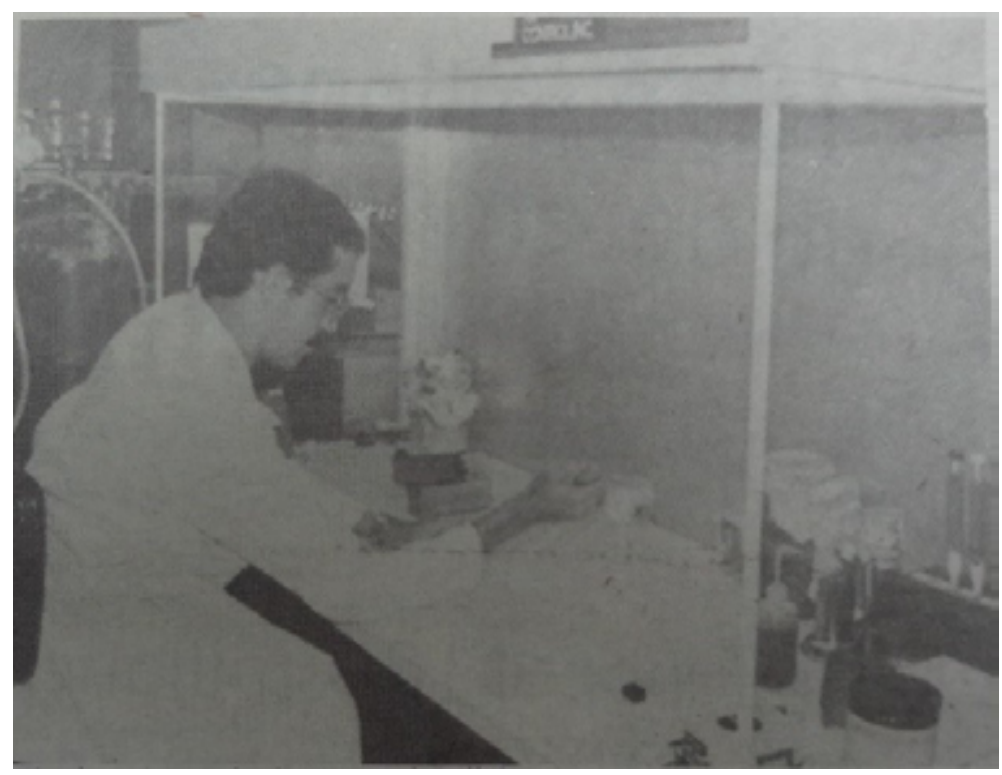

Fuente: Monge. (2 de setiembre de 1985).
Imagen 5. El INISA realiza estudios sobre anticuerpos de SIDA

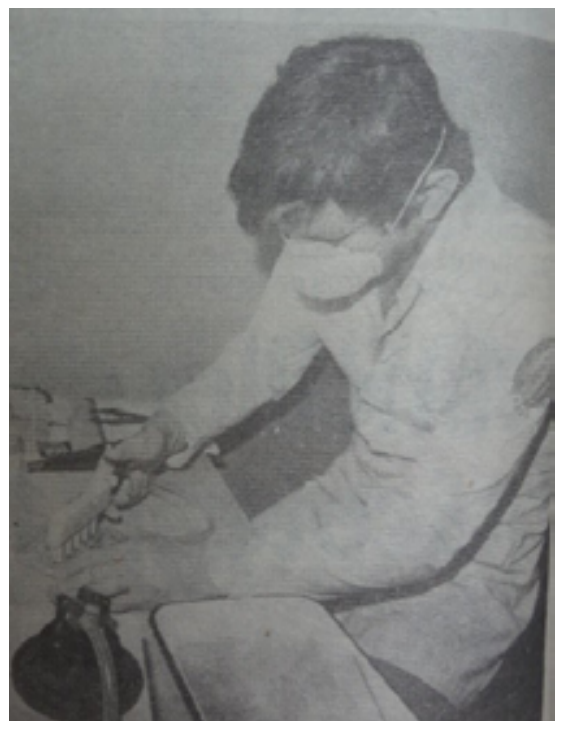

Fuente: El INISA realiza estudios sobre anticuerpos de SIDA (4 de setiembre de 1985).

Una de las respuestas estatales que causó más polémica, fue la posibilidad de hacer obligatorias las pruebas que confirmaban la presencia del $\mathrm{VIH}$ en personas pertenecientes a ciertos sectores del país. En una fotografía que ocupó la portada de La Nación, el 25 de marzo de 1987, aparecen miembros del gabinete, encabezados por el Dr. Edgar Mohs como Ministro de Salud, sometiéndose a la realización de un sangrado para el correspondiente examen que determinaría el estado serológico de los funcionarios ${ }^{4}$. Es de destacar que el profesional en salud encargado de hacer el procedimiento aparece utilizando una gabacha, así como también un instrumental médico necesario para su labor. Así mismo, aparece en el fondo una pizarra con una escritura que no es legible para quien observe la imagen. La aparición de este último elemento, al igual que en una de las imágenes anteriormente abordadas, es fácilmente asociada con la transmisión de conocimiento verídico, así como también con la investigación médica, de tal forma que consiste en un objeto que refuerza la idea de un saber institucionalizado fidedigno.

${ }^{4}$ Una imagen muy similar se publica el 12 de mayo de 1987, donde se informa que se han hecho 6 mil pruebas de ELISA en el país, y aparece igualmente un doctor con gabacha efectuando un sangrado a un hombre vestido formal con el rostro visible. 
En relación con estos elementos que permiten connotar un conocimiento médico a través de las fotografías, es importante indicar que, de forma paralela a las discusiones médico-científicas, existía un sector de la población directamente afectado por el padecimiento, que era poseedor de un conocimiento veraz sobre las formas de transmisión. Estos sectores, principalmente conformados por personas trabajadoras sexuales, no contaban con una plataforma mediática que posibilitara la difusión de otras fuentes de información. Mientras que los médicos continuaban utilizando las plataformas mediáticas para intercambiar criterios que, en diversas ocasiones, contaban con datos erróneos (Jiménez y Soto, 2018).

Imagen 6. Prueba de SIDA provoca polémica

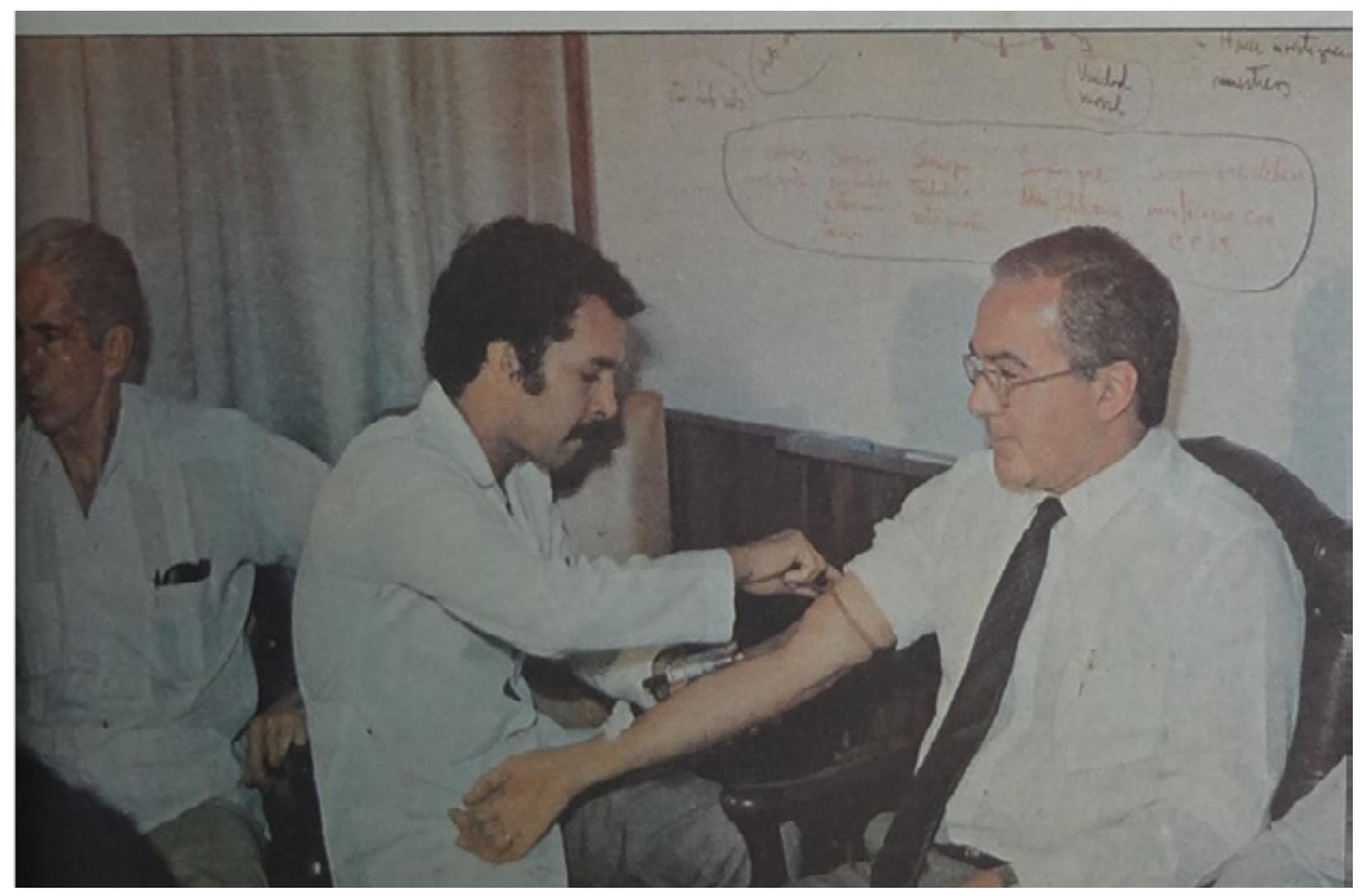

Fuente: Prueba de SIDA provoca polémica (27 de marzo, 1987). 
Fotografías del sida:

médicos y homosexuales en la prensa costarricense (1985-1990)

Ante la masiva presencia de médicos hombres, destaca la casi total ausencia de las mujeres, pues solamente una pasa a formar parte del grupo de voceros a los que acuden los medios de comunicación. Se trata de la Dra. Guiselle Herrera, infectóloga del Ministerio de Salud, quien aparece solamente en dos ocasiones en el periódico La Nación. La primera fotografía es del 17 de marzo de 1987. La infectóloga aparece sentada frente a un escritorio, con un cuaderno abierto, la mujer no porta gabacha -que como se ha visto es la usanza de sus colegas- y al fondo es posible observar un teléfono fijo. Estos objetos que son presentados en la composición de la fotografía se relacionan más con la profesión de secretaria que con la de cualquier disciplina vinculada con el área de salud, o bien la generación y transmisión de conocimiento, que es, justamente, a lo que aboca el texto que acompaña la fotografía: ritmo de crecimiento de la cantidad de personas infectadas, número de casos reportados, poblaciones a las que pertenecen y la reiteración de medidas preventivas.
Imagen 7. Tres casos más de SIDA

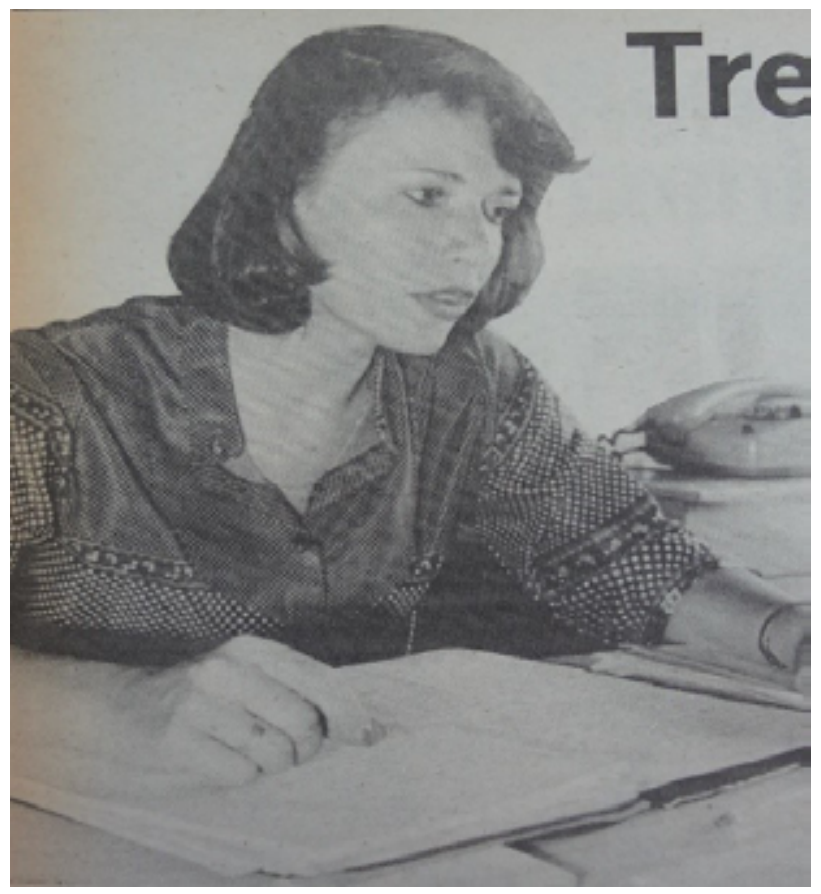

Fuente: Tres casos más de SIDA (17 de marzo de 1987).

La segunda imagen correspondiente a la Dra. Guiselle Herrera, aparece el 17 de mayo de 1987, en esta se presentan al menos dos diferencias sustanciales con respecto a la anterior. La mujer porta una gabacha blanca, además, está sonriendo y dirige su mirada hacia el borde superior derecho del recuadro, con un aire optimista, mientras sostiene un lapicero, con el cual parece anotar algo en un cuaderno que queda oculto para quien observa la fotografía. De primera entrada, la imagen parece entrar en contradicción con el texto que la acompaña, ya que la noticia informa sobre la cantidad de exámenes que se han realizado a la fecha, los cambios en el patrón epidemiológico del virus, ya que se pasó de los hemofílicos como el grupo más afectado a un relevo homosexual en cantidad de casos infectados detectados. De esta forma, por asociación entre imagen y texto, la mujer -en representación del gremio médico y por decisión editorial- parece alegrarse de este cambio, a pesar de que la condición de salud continuaba significando, para esa fecha, sinónimo de muerte. 
Imagen 8. 63 mil exámenes de SIDA en el país

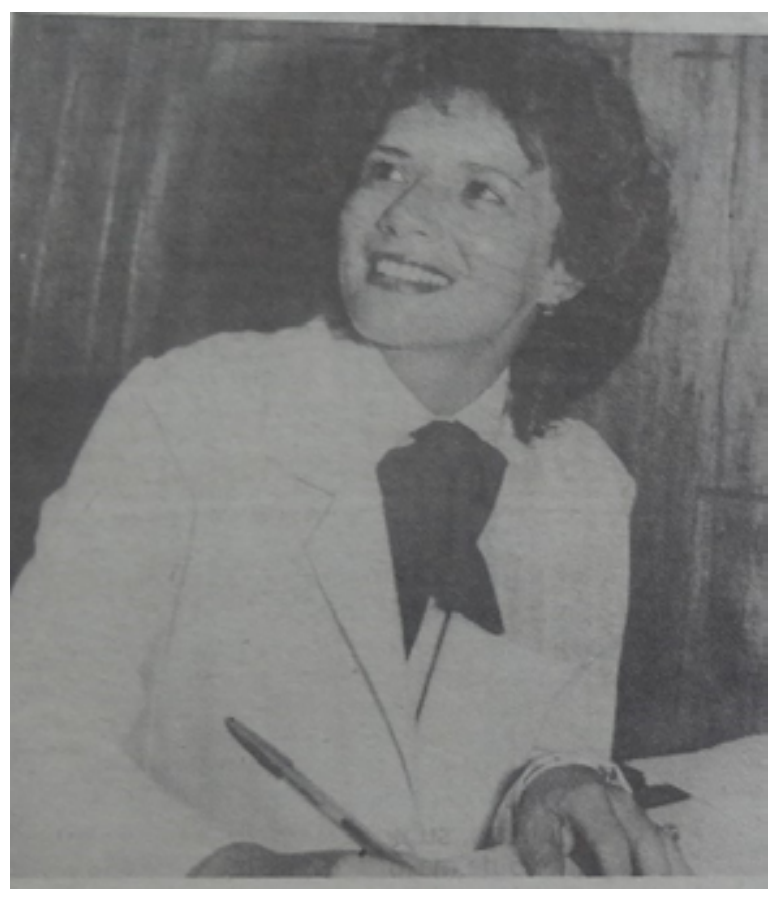

Fuente: Solís, M. (17 de mayo de 1987).
Finalmente, cabe resaltar que la noticia en la que se encuentra esta segunda imagen fue escrita por una mujer.

\section{La política de la vergüenza: del exotismo al ocultamiento del rostro homosexual}

Junto a los médicos, el otro grupo que cobró protagonismo en las fotografías utilizadas en los medios de comunicación fue el de los "homosexuales". No obstante, la forma en que ambos grupos fueron presentados fue completamente antagónica. Mientras que, los médicos eran retratados de frente, en posición de autoridad, con poses que daban a entender un saber institucionalizado; los homosexuales, paulatinamente, fueron perdiendo el rostro, una vez que en 1987 se convierten en el sector más afectado por la infección. Además, empezó a desarrollarse una política de la vergüenza, en donde el rostro era ocultado y censurado.

El 2 de setiembre de 1985 se publica un reportaje en el que una periodista entrevista a tres "travestidos", los cuales son equiparados a "homosexuales que se visten de mujer". Es interesante apreciar la poca especificidad para nombrar a los sujetos que interroga, ya que agrupa bajo un mismo término a una serie de categorías identitarias históricamente diferenciadas para la época. Dicha confusión conceptual aparece de manera recurrente en muchos de los discursos que abordaron a estos sectores de la población durante la década de 1980. En la fotografía se presentan cuatro mujeres, tres de ellas sentadas en una cama pequeña y una cuarta se encuentra de pie, mirándolas. La que se presume sería la periodista, se encuentra en el centro de la escena y parece tomar apuntes en un cuaderno que sostiene en una de sus manos. El único rostro que es posible observar es el de una de las entrevistadas, que se encuentra detrás de la periodista y dirige su mirada al cuaderno de esta. El protagonismo de la periodista en la captura fotográfica hace pensar en el heroísmo con que se suele retratar a algunos antropólogos mientras realizan trabajo de campo en sociedades "salvajes", en tanto se les reconoce como "valerosos" por adentrarse en mundos a los que no cualquiera se atreve a entrar. 
Fotografías del sida:

Imagen 9. A veces cuando nos ven nos gritan SIDA

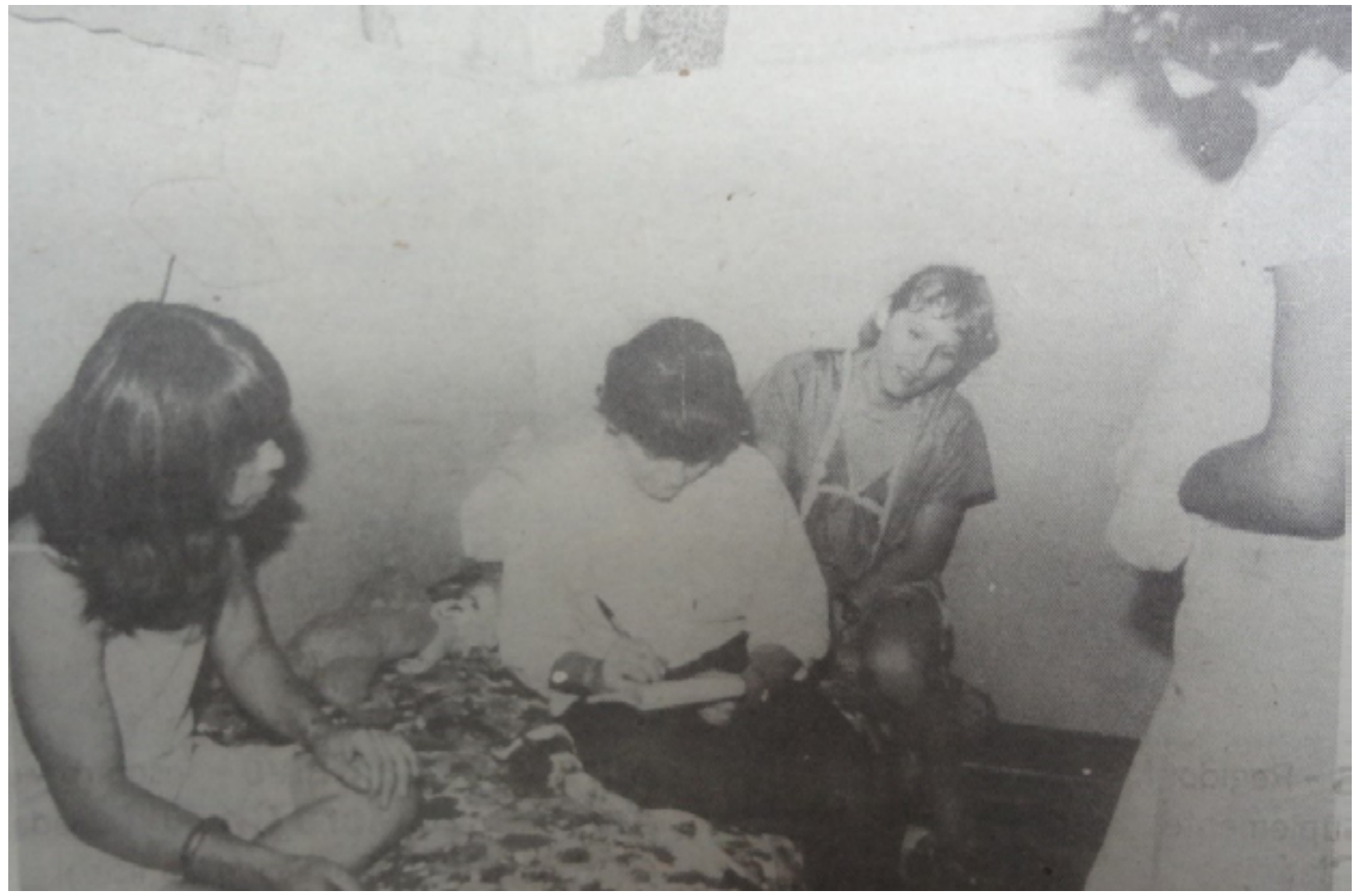

Fuente: A veces cuando nos ven nos gritan SIDA. (2 de setiembre de 1985). La Nación, (El País), p. 12.

En línea con los señalamientos anteriores, además es posible apreciar que el texto de la noticia hace una serie de apreciaciones etnográficas sobre el espacio: "un pequeño pero ordenado cuarto en las cercanías de la parada de la Coca Cola", "el cuarto huele a cera -'Jenifer' aclara que acaba de encerar-, fotos de artistas y cantantes adornan la habitación, donde también resaltan un televisor, un equipo de sonido y un cuadro de una virgen arrullando a su niño". ("A veces cuando nos ven nos gritan SIDA", 2 de setiembre de 1985, p.12). De esta forma, parece quedar inaugurada una serie de excursiones que los medios de comunicación hicieron para tratar de "conocer" a esa "exótica" población que hasta esa época parecía haber estada condenada al anonimato.

En otro reportaje continúa el descubrimiento del exótico mundo homosexual, que además se ha comenzado a tornar cada vez más amenazante, ya que se indica en la portada del periódico que: 
Ahora se sabe... que existe una población sexual variada y compleja que aparentemente se multiplica, que desprejuiciadamente se ha lanzado a la calle sin los temores de antes, que se prepara para reafirmar sus derechos y que se hace cada vez más agresiva (SIDA revela actividad de homosexuales, 18 de mayo de 1987, p. 5)

En las dos fotografías que acompañan dicha publicación, es posible observar a varias mujeres posando de manera gustosa, incluso sonriendo. En esta ocasión -al contrario de lo que se vio para la noticia de 1985- hay una barra que censura los ojos. Este ocultamiento de la mirada puede tener varias significaciones, dentro de las cuales -y en línea con el contexto y lo planteado en la noticia- está la peligrosidad y la criminalización de esta población dedicada al trabajo sexual. Además, se les adjudica una atmósfera de misticismo, como lo narra el viceministro de gobernación, Álvaro Ramos: "al incursionar en ellos, me encontré un ambiente de superstición, una mezcla de religión con sexo, practicada por gente de condición baja" (SIDA revela actividad de homosexuales, 18 de mayo de 1987, p. 5). Una vez más, es posible notar el discurso del exotismo.

Imagen 10. SIDA revela actividad de homosexuales

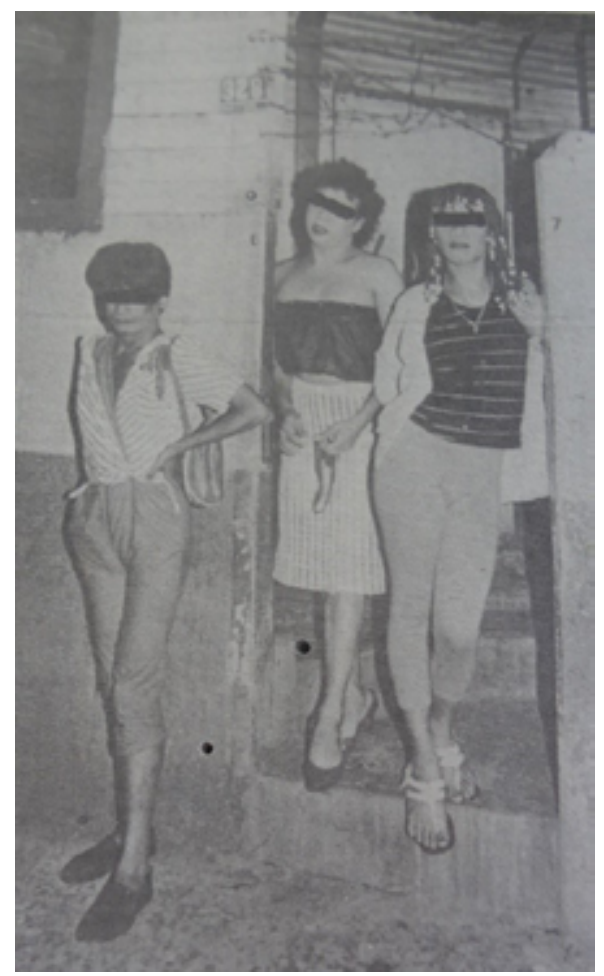

Imagen 11. SIDA revela actividad de homosexuales

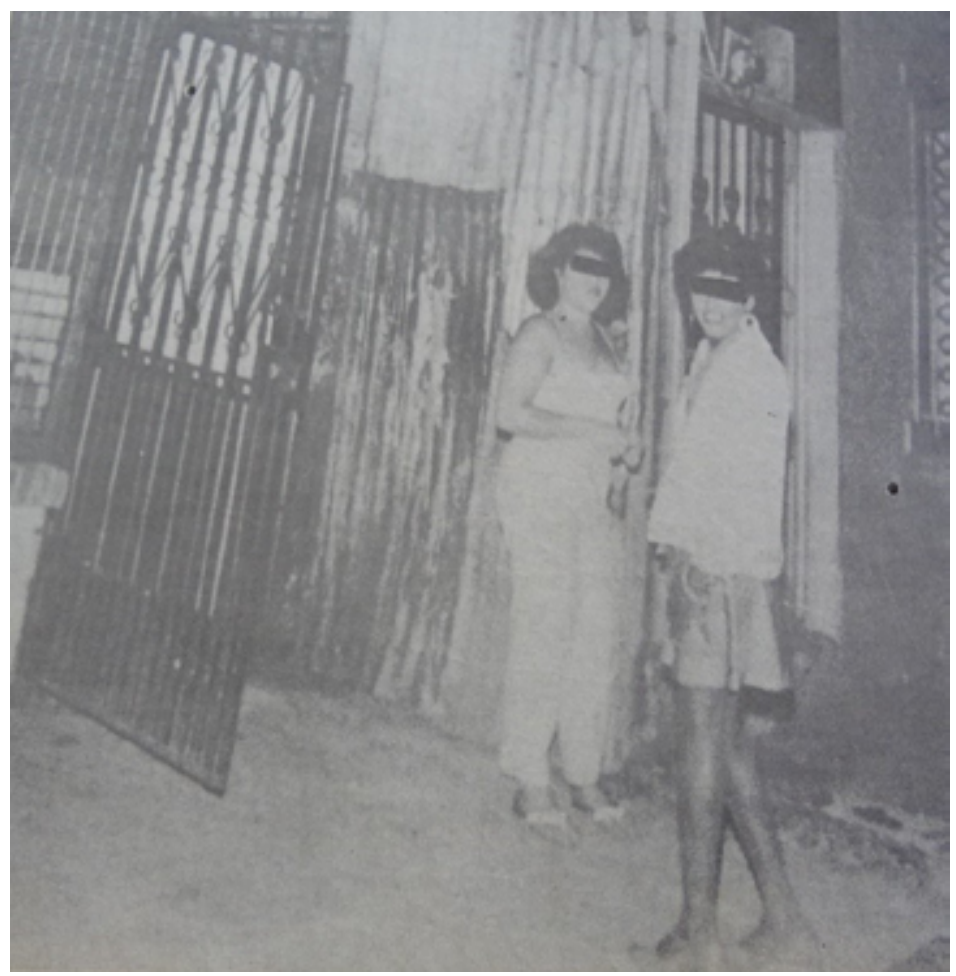

Fuente: SIDA revela actividad de homosexuales. (18 de mayo de 1987). 
Fotografías del sida:

Artículos médicos y homosexuales en la prensa costarricense (1985-1990)

Para continuar con las imágenes, es posible apreciar que el escenario donde se encuentran los sujetos corresponde a un contexto empobrecido: paredes de madera desgastada, latas que funcionan como paredes, entradas estrechas, piso de obra gris, puertas endebles, alambres de púas. En la noticia se hace referencia a los lugares "conquistados" por los homosexuales, principalmente, aquellos cercanos al Cine Líbano y los alrededores de la Coca Cola, espacios urbanos caracterizados por un proceso sistémico de marginalización y empobrecimiento. En el pie de foto se afirma que "los investigadores esperan que los homosexuales cambien sus hábitos" y "no les gusta que los llamen por sus nombres masculinos". Una vez más sale a relucir el saber científico y la regulación sexo/género dicotómico.

Es de interés destacar el hecho de que los cuerpos de "homosexuales" presentados en estas noticias, no corresponden al típico cuerpo "sidoso". Es decir, debilitados, desgastados y al borde la muerte ${ }^{5}$. Tal como se pudo ver en las imágenes anteriormente presentadas, el retrato que se hace de la homosexualidad está vinculado con la pobreza y la criminalidad. Además, se presenta como amenazante, por lo que cabe preguntarse ¿qué es lo que hace viable que se puedan presentar estas imágenes? A partir de las reflexiones realizadas por Bersani (1998) es posible afirmar que la presencia del sida vuelve a los homosexuales "fascinantes" y, por ende, material para ser mostrado en medios de comunicación: "la mayor visibilidad que el sida otorgó a los gays es la de la muerte inminente, la de una prometida invisibilidad [futura]" (p. 53).

No resulta azaroso detectar un cambio en las fotografías referentes a la homosexualidad a partir del momento en el que se empieza a hablar del AZT, medicamento que revoluciona este padecimiento, ya que pasa de ser una enfermedad mortal a una crónica. De esta forma, la "fascinación" anterior por el exotismo de lo homosexual, pasa a ser sustituida por una representación de parejas del mismo sexo sosteniendo una pose fácilmente asociada con la vergüenza. En un reportaje del 26 de abril de 1987, se habla sobre la experiencia del AZT en varios países y las gestiones que deben llevar a cabo las autoridades salud nacionales para poder acceder a dicho medicamento.

En la fotografía que acompaña el artículo, se puede observar dos hombres de espaldas, agarrados de la mano y con la cabeza baja, la mano que tienen libre la tienen dentro de los bolsillos del pantalón y la ropa que utilizan es casual. Este es un cambio radical en torno a la forma en que se representa la homosexualidad por medio de fotografías. Una vez que la muerte no es inminente y se empieza a vislumbrar la posibilidad de que las personas portadoras del virus tengan una expectativa de vida más prolongada, la representación de la homosexualidad pasa a ocupar una pose de vergüenza y anonimato. El rostro que antes

${ }^{5}$ Una de las pocas excepciones se encuentra en Herrera, F. (16 de junio de 1988).

ESCENA. Revista de las artes, 2019, Vol. 78, Núm. 2 (enero-junio), pp. 125-149 
Imagen 12. Intentan traer droga para pacientes con SIDA

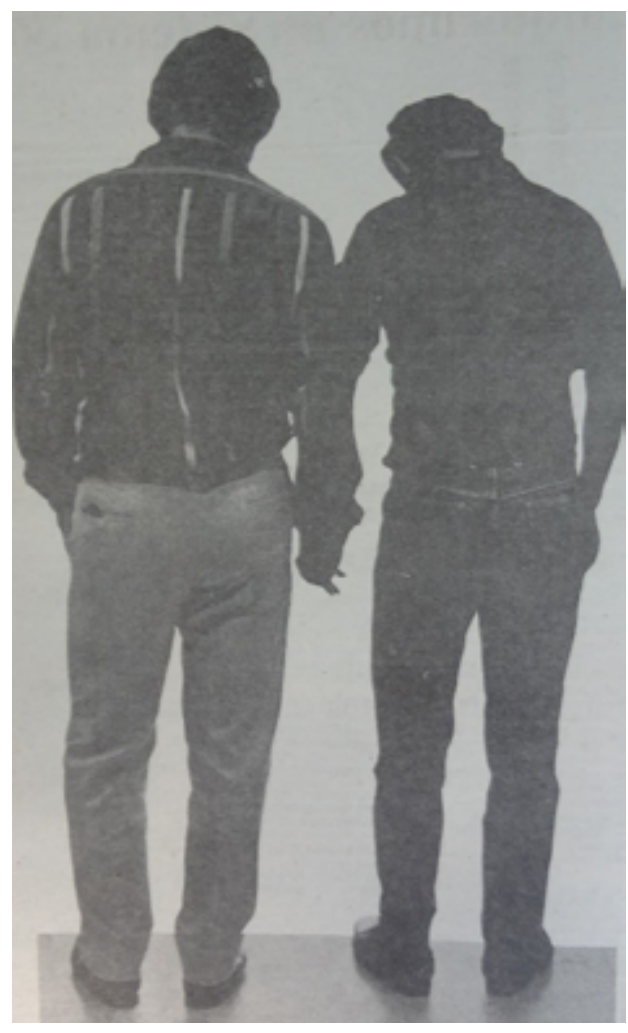

Fuente: Solís, 25 de abril de 1987. aparecía de frente o con la mirada censurada, ahora está completamente ausente del encuadre ${ }^{6}$. En contraposición a esto, es posible encontrar múltiples noticias donde los médicos que se dedican a dar declaraciones sobre el $\mathrm{VIH} /$ sida son presentados a partir de retratos. De esta forma, la imagen del supuesto "sidoso" queda velada por el claroscuro de la vergüenza, que oculta su mirada y esconde su rostro. Mientras que la del médico es exaltada y colocada en un primer plano, donde incluso se incluyen sus nombres, sus puestos y sus descubrimientos.

\section{Conclusiones}

Al analizar las fotografías utilizadas para retratar el VIH/sida en el periódico La Nación, durante el periodo 1985-1990, ha sido posible abordar una serie de temáticas que van más allá del contenido de sus textos. Tal como se indicó al inicio de este escrito, con esto se destaca la importancia de realizar otra serie de lecturas que hagan énfasis en las representaciones visuales. Tomando en cuenta la ubicuidad de los discursos biomédicos en nuestros tiempos, la posibilidad de hacer abordajes que tengan en cuenta lo estético y lo artístico constituyen una posibilidad de cuestionar la aparente consistencia de los discursos cientificistas que -tal como se pudo observar- están cargados de prejuicios y violencias.

Partiendo de la premisa de que la complementariedad entre imagen y texto es una decisión editorial y al sacar de la ecuación la posibilidad de pensar que algunas yuxtaposiciones de estas dos estructuras son "errores" de diagramación, es posible desprender del vínculo entre la fotografía y el texto, una serie de connotaciones que funcionan como metáforas del desarrollo de la enfermedad. La primera noticia analizada presenta una relación

6 Este tipo de representación se repite en diferentes noticias de otros periódicos, ver Schifter, J. (17 de julio de 1987); Molina, C. (7 de julio de 1989); Atención pastoral a homosexuales (2 de agosto de 1987).

ESCENA. Revista de las artes, 2019, Vol. 78, Núm. 2 (enero-junio), pp. 125-149 
Fotografías del sida:

Artículos médicos y homosexuales en la prensa costarricense (1985-1990)

entre las graves proyecciones del virus y las consecuencias de una inundación. Mientras que la segunda establece un enlazamiento entre la avanzada del sida a nivel mundial y el avance de los grupos civiles de homosexuales en búsqueda de la igualdad de derechos. En ambos casos, pareciera haber de primera entrada una contradicción entre imagen y texto, sin embargo, dicha "incoherencia" permite interpretar múltiples connotaciones.

En lo que respecta a la forma en que son representados los médicos involucrados en la discusión mediática sobre el $\mathrm{VIH} /$ sida, se evidencia una estética bastante uniforme: mayoritariamente hombres, uso de gabachas, laboratorios, instrumental médico, pizarras, primeros planos, rostros visibles, poses confiadas y profesionales. Los medios de comunicación fueron una plataforma que le permitió a los médicos convertirse en el rostro de autoridad, en la cara exclusiva del saber científico y verídico sobre las características del padecimiento. En el caso de las mujeres, solo aparece una y con ciertos contrastes que la alejan de estas representaciones uniformes.

Finalmente, las fotografías utilizadas para representar a la homosexualidad desarrollan -en cuestión de unos pocos años- cambios bastante notables. Un interés mediático inicial le da rostro a los travestidos, utilizando una narrativa periodística casi etnográfica. Una vez que en 1987 el mayor número de afectados por el VIH pasan a ser los homosexuales, se despliega una criminalización de la mano con la supuesta amenaza y peligrosidad que estos grupos representaban para el grueso de la sociedad: las fotografías empiezan a censurar la mirada de los sujetos. Para cuando la discusión sobre el AZT y los posibles medicamentos empieza a relucir, se articula una política de la vergüenza que incide en la estética de las fotografías: los homosexuales pasan a ser anónimos, de espaldas, con la cabeza baja y en pose de retraimiento, en contraposición a la visibilidad de los médicos.

Durante la segunda mitad de la década de 1980 se configuró un discurso que criminalizaba, condenaba y colocaba a la homosexualidad en el lugar de lo abyecto. Las injurias que se desplegaron en varios artículos periodísticos son una evidencia de esta dinámica (Jiménez, 2016). Asimismo, es posible apreciar la manera en que las fotografías aquí abordadas proponen imágenes específicas sobre las diversas aristas que estuvieron en juego durante el desarrollo de la pandemia: las metáforas del desastre natural, las metáforas militares, el protagonismo médico y una homosexualidad que oscila entre el exotismo y el ocultamiento por vergüenza. Con relación a este último punto, interesa destacar que la fotografía llega ser partícipe de la construcción de la injuria por medio de la cual, se ha caracterizado a un grupo poblacional particular. Sobre esto Eribon (2004) dice lo siguiente:

La injuria es un haz luminoso que dibuja en la pared una imagen grotesca del individuo paria, y lo transforma en un animal fantástico, en una quimera, a la vez imaginario (no existe más que como el producto de miradas fóbicas) y real (pues se convierte en la

ESCENA. Revista de las artes, 2019, Vol. 78, Núm. 2 (enero-junio), pp. 125-149 
definición misma de la persona así transfigurada...). La identidad asignada a un individuo a través de la estigmatización no es, pues, más que el producto de una expulsión, más allá de la frontera que separa lo normal de lo patológico, de todo lo que la sociedad considera como su negativo. Sin embargo, de esta misma expulsión nace un personaje dotado en adelante de una "naturaleza" (a su vez herencia y reproducción de una larga historia colectiva del orden social y sexual). Esta "naturaleza" se convierte en la realidad, la verdad del individuo [énfasis agregado] (p. 72).

La injuria y la vergüenza forman parte fundamental de la historia de la homosexualidad. La celebración del orgullo -cuyo surgimiento es el producto de un proceso histórico, que se empieza a formar, principalmente, en la década de 1980 a partir del activismo y la formación de grupos organizados en búsqueda de derechos- que actualmente caracteriza la visibilidad política de estos grupos, quedaría incompleta sin una adecuada y crítica reflexión sobre el papel que han tenido estos dos elementos en la configuración de las subjetividades. Así como las representaciones visuales posteriores sobre la diversidad sexual se han caracterizado por su gran colorido, las metáforas fotográficas destacadas en la anterior cita de Eribon (2004) dan cuenta de la necesidad de seguir explorando este tipo de temáticas y enfoques.

\section{Referencias}

A veces cuando nos ven nos gritan SIDA. (2 de setiembre de 1985). La Nación, p. 12.

Aclaran que riesgo de contraer SIDA es alto en ciertos grupos. (29 de agosto de 1985). La Nación, p. 2.

Atención pastoral a homosexuales. (2 de agosto de 1987). Eco Católico, p. 6.

Avanza el SIDA. (11 de enero de 1987). La Nación, p. 6.

Barthes, R. (2016). La cámara lúcida. Nota sobre la fotografía. Paidós: Barcelona.

Barthes, R. (2015). Lo obvio y lo obtuso. Imágenes, gestos y voces. Paidós: Barcelona.

Bersani, L. (1998). Homos. Buenos Aires: Manantial.

Bleiker, R. \& Kay, A. (2007). Representing HIV/AIDS in Africa: Pluralist photography and local empowerment. International Studies Quarterly, 51(1), 139-163.

Crece número de personas con anticuerpos de SIDA. (25 de enero de 1987). La Nación, p. 4.

Divergen sobre examen de SIDA. (25 de marzo de 1987). La Nación, p. 11.

Dos casos más de SIDA en el país. (22 de agosto de 1987). La Nación, p. 8. 
Fotografías del sida:

Artículos

médicos y homosexuales en la prensa costarricense (1985-1990)

Dubois, P. (2015). El acto fotográfico y otros ensayos. Buenos Aires: La Marca Editora.

El INISA realiza estudios sobre anticuerpos de SIDA. (4 de setiembre de 1985). La Nación, p. 2.

Eribon, D. (2004). Una moral de lo minoritario. Variaciones sobre un tema de Jean Genet. Barcelona: Anagrama.

Grmek, M. (2004). La historia del sida. Buenos Aires: Siglo Veintiuno Editores.

Herrera, F. (16 de junio de 1988). EI SIDA gobierna en América. Contrapunto, p. 10.

Investigarán uso de droga contra SIDA. (12 de mayo de 1987). La Nación, p. 4.

Jiménez, J. y Soto, M. (2018). El Sida y los debates médico-científicos en Costa Rica. En: I. Molina y D. Díaz (Eds.), Ahí me van a matar. Cultura, violencia y Guerra Fría en Costa Rica (1979-1990). Costa Rica: EUNED (en prensa).

Jimenez, J. \& Bahena, M. (2017) Entre la ciencia y la cultura: La conformación de discursos médicos sobre la homosexualidad en el contexto del surgimiento del $\mathrm{VIH} /$ Sida en Costa Rica. Anuario de Estudios Centroamericanos, 43, 419-445.

Jiménez, J. (2016). La criminalización de la diversidad sexual y el inicio del activismo gay en Costa Rica, 1985-1989. Revista Rupturas, 6(1), pp.61-90.

Johnny, L. \& Mitchell, C. (2007). Live and let live: An analysis of HIV/AIDS-related stigma and discrimination in international campaign posters. Journal of Health Communications: International Perspectives, 11(8), 755-767.

Marginan a alumnos hijos de pacientes con SIDA. (15 de mayo de 1987). La Nación, p. 6.

Mata, L. (1998). El SIDA en Costa Rica, a finales de 1988. Revista Costarricense de Ciencias Médicas, 9(3), pp.1-5.

Monge, R. (2 de setiembre de 1985). Dudas y mitos que deben desecharse. La Nación, p. 12.

Molina, C. (7 de julio de 1989). Desorden sexual es el abono del SIDA. La Prensa Libre, p. 2.

Niegan discordia entre médicos por el SIDA. (14 de abril de 1987). La Nación, p. 8.

Limitarán prueba de SIDA. (7 de abril de 1987). La Nación, p. 10.

Oyebode, O. \& Unuabonah, F. (2013). Coping with HIV/AIDS: A multimodal discourse analysis of selected HIV/AIDS posters in south-western Nigeria. Discourse \& Society, 24(6), 810-827.

Pretenden ampliar exámenes de SIDA. (5 de enero de 1987). La Nación, p. 2.

Primeros dos casos de SIDA en 1988. (8 de enero de 1988). La Nación, p. 5.

ESCENA. Revista de las artes, 2019, Vol. 78, Núm. 2 (enero-junio), pp. 125-149 
Proponen examen del SIDA a funcionarios públicos. (24 de marzo de 1987). La Nación, p. 4. Prueba de SIDA provoca polémica. (27 de marzo de 1987). La Nación, p. 1

Schifter, J. (17 de julio de 1987). Miedo irracional a los homosexuales. Semanario Universidad, p. 12.

SIDA provoca una muerte más. (5 de abril de 1987). La Nación, p. 4.

Sida revela actividad de homosexuales. (18 de mayo de 1987). La Nación, p. 5.

Sontag, S. (2014). La enfermedad y sus metáforas. El sida y sus metáforas. Madrid: Editorial Debolsillo.

Solís, M. (25 de abril de 1987). Intentan traer droga para pacientes con SIDA. La Nación, p. 6.

Solís, M. (17 de mayo de 1987). 63 mil exámenes de SIDA en el país, La Nación, p. 5.

Solís, M. (4 de julio de 1987). Hallan anticuerpos de SIDA en hemoderivados. La Nación, p. 6.

Smirnow, G. (27 de enero de 1985). Científicos identifican virus que causa el SIDA. La Nación, p. 20.

Soto, M. (2017). Otredad, exclusión social y resistencia: una lectura psicoanalítica de la novela Paisaje con tumbas pintadas en rosa de José Ricardo Chaves (Tesis de Maestría). Universidad de Costa Rica. San José, Costa Rica.

Tres casos más de SIDA. (17 de marzo de 1987). La Nación, p. 8

Usarán derivados sanguíneos sólo en casos de urgencia. (10 de julio de 1987). La Nación, p. 8.

Varas-Díaz, N. \& Toro-Alfonso, J. (2003). Incarnating stigma: Visual images of the body with HIV/AIDS. Forum: Qualitative Social Research, 4(3). Recuperado de http://nbn-resolving. de/urn:nbn:de:0114-fqs030375. 